\title{
Perbandingan Algoritma Klasifikasi terhadap Emosi Tweet Berbahasa Indonesia
}

\author{
Arif Bijaksana Putra Negara ${ }^{\# 1}$, Hafiz Muhardi ${ }^{\# 2}$, Fahmi Sajid ${ }^{\# 3}$

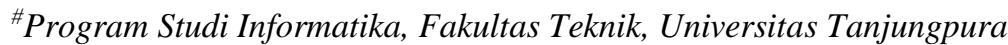 \\ Jl.Prof. Dr.H.Hadari Nawawi, Pontianak, 78124 \\ 1arifbpn@informatika.untan.ac.id \\ 2hafizmeinformatika.untan.ac.id \\ sfahmisajidestudent.untan.ac.id
}

\begin{abstract}
Abstrak - Twitter merupakan jejaring sosial dimana tempat orang-orang mengutarakan ekspresi dan emosi dirinya dalam bentuk tulisan. Mengidentifikasi emosi di Twitter tidak bisa menggunakan teknik text processing yang sederhana, karena kalimat pada Twitter yang singkat dan tata bahasa yang tidak teratur. Tujuan penelitian ini adalah untuk mengetahui algoritma yang mempunyai kinerja paling baik dalam menentukan klasifikasi emosi tweet pengguna Twitter Indonesia. Algoritma yang digunakan pada penelitian ini adalah Logistic Regression dan K-Nearest Neighbor. Dan juga pada penelitian ini melihat pengaruh TF-IDF dan Tuning Hyperparameter pada kedua algoritma. Hasil evaluasi menunjukkan bahwa performa model menggunakan algoritma logistic regression dengan feature extraction TFIDF dan Tuning Hyperparameter memberikan perfoma model paling baik dengan nilai accuracy dan f1-score masingmasing sebesar $65 \%$ dan $66 \%$. Model tersebut digunakan sebagai model prediksi machine learning untuk mengklasifikasikan dan mengelompokkan emosi-emosi pada aplikasi generik yang dibangun pada penelitian ini.
\end{abstract}

Kata kunci- Machine Learning, Text Mining, Emotion Classification, K-Nearest Neighbors, Logistic Regression

\section{Pendahuluan}

Media jejaring sosial merupakan tempat orang-orang mengekspresikan dirinya dalam bentuk tulisan, gambar, serta Video. Twitter Sebagai media sosial, Twitter mempunyai fungsi bertipe micro-blogging yaitu blog berukuran kecil dengan maksimal 140 karakter jumlah karakter dalam tweet atau post dalam twitter [1].

Twitter biasanya dimanfaatkan oleh instansi/lembaga atau perorangan untuk menyampaikan informasi dalam bentuk teks dan mendapatkan umpan balik dari apa yang disampaikan dalam informasi tersebut. Tidak hanya menyampaikan informasi saja, pengguna twitter juga dapat mengekspresikan emosinya [2]. Namun, emosi yang diungkapkan oleh masyarakat sangat beragam jenisnya. Strukutur kosa kata emosi dalam bahasa Indonesia telah didefinisikan oleh Shaver dan Murdaya [3]. Terdapat lima kelas emosi dalam bahasa Indonesia yaitu cinta (love), senang (happiness), marah (anger), kawatir/takut (anxiety/fear), dan sedih (sadness)

Mengidentifikasi emosi di Twitter tidak bisa menggunakan teknik text processing yang sederhana, karena kata pada Twitter yang singkat dan tata bahasa yang tidak teratur. Oleh karena itu dibutuhkan teknik text mining untuk mengekstrak kata" tidak terstruktur tersebut yang akan digunakan untuk membuat sebuah model prediksi machine learning yang dapat mengklasifikasikan dan mengelompokkan emosi-emosi tersebut, sehingga dapat mengurangi waktu dan biaya untuk mengidentifikasi emosi pada suatu kalimat. Algoritma klasifikasi terdiri dari beberapa cara, diantaranya menggunakan algoritma Naïve Bayes, Support Vector Machine, C4.5, Artificial Neural Network (ANN), K-Nearest Neighbors dan lainnya. Setiap algoritma mempunyai caranya tersendiri untuk mengklasifikasi, hasil kinerjanya juga bergantung pada kasus masalah, data yang digunakan, dan faktor lainnya.

Penelitian terkait klasifikasi emosi, khususnya teks Bahasa Indonesia telah dilakukan, diantaranya oleh: (a) Johanes et $\mathrm{Al}$ mengusulkan pendekatan dua tahap untuk deteksi emosi pada tweet Indonesia. Tahap yang pertama, tweet yang mengandung emosi dari sejumlah besar tweet mentah diekstraksi. Semua tweet yang diekstrak kemudian diklasifikasikan ke dalam lima kelas emosi yang telah ditentukan sebelumnya, yaitu cinta, kegembiraan, sedih, ketakutan, dan kemarahan menggunakan model komputasi berdasarkan pendekatan machine learning yang menggunakan berbagai bahasa, semantic dan ortografis [4] (b) Saputri, dkk mengklasifikasikan emosi kedalam 5 kelas emosi (love, joy, anger, sadness, fear) dengan membandingkan algoritma klasifikasi Logistic Regression, SVM, dan Random Forest dan menggunakan kombinasi feature extraction [5]. Pada bahasa yang lain Alm et al. membahas masalah prediksi emosi berbasis teks dalam domain dongeng anak-anak menggunakan supervised machine learning [6].

Adapun penelitian terkait klasifikasi teks: Tomas \& Viginjus menggunakan classifier Naive Bayes, Decision Tree, Support Vector Machine dan Logistic Regression 
untuk mengklasifikasi Text Review dari Amazon customer's dan Bag of word sebagai fitur ekstraksinya. Hasilnya kinerja classifier Logistic Regression lebih baik daripada classifier Naïve Bayes, Random Forest, Decision Tree, dan Support Vector Machines [7].

Muhammad Azam mengklasifikasikan scientific publications kedalam enam kelas (Medicine, Mathematic, Finance, Agricultural \& Biological, Sciences, and Engineering) berdasarkan abstrak dan sitasi jurnal. Dataset yang digunakan sebanyak 10.000 abstrak. Algoritma klasifikasi yang digunakan yaitu Bayes dan K-Nearest Neighbors [8].

Teknik klasifikasi emosi yang digunakan pada penelitian ini adalah teknik klasifikasi Logistic Regression dan $K$ Nearest Neighbors. Kedua teknik klasifikasi ini akan dibandingkan dan kemudian teknik klasifikasi yang kinerjanya paling baik akan digunakan untuk membangun model dalam menentukan klasifikasi emosi pada aplikasi generik yang dibangun. Tidak hanya membandingkan teknik klasifikasi tetapi penelitian ini juga membandingkan hasil antara jika model menggunakan TF-IDF dan Tuning Hyperparameter.

\section{Metodologi}

Terdapat lima tahap metode penelitian yang dilakukan pada penelitian ini yang dapat dilihat pada Gambar 1 untuk membangun model machine learning.

\section{A. Pengumpulan Data}

Untuk membuat suatu model machine learning dibutuhkan suatu data pembelajaran. Data pembelajaran pada penelitian ini berupa teks. Data yang digunakan berasal dari penelitian Saputri, Mahendra, dan Adriani (2019) yang berjudul "Emotion Classification on Indonesian Twitter Dataset" [5]. Penelitian mereka bertujuan untuk membuat Indonesian twitter dataset untuk tugas klasifikasi dan untuk disebarluaskan. Data diambil menggunakan Twitter Streaming API sekitar 2 minggu, dimulai dari 1 Juni 2018 hingga 14 Juni 2018. Dataset ini memiliki 4403 Indonesian Tweets dimana sudah terlabel kedalam lima kelas emosi yaitu: "love", "anger", "sadness", "happy", dan "fear" (lihat Tabel 1). Contoh kalimat dapat dilihat pada Gambar 2.

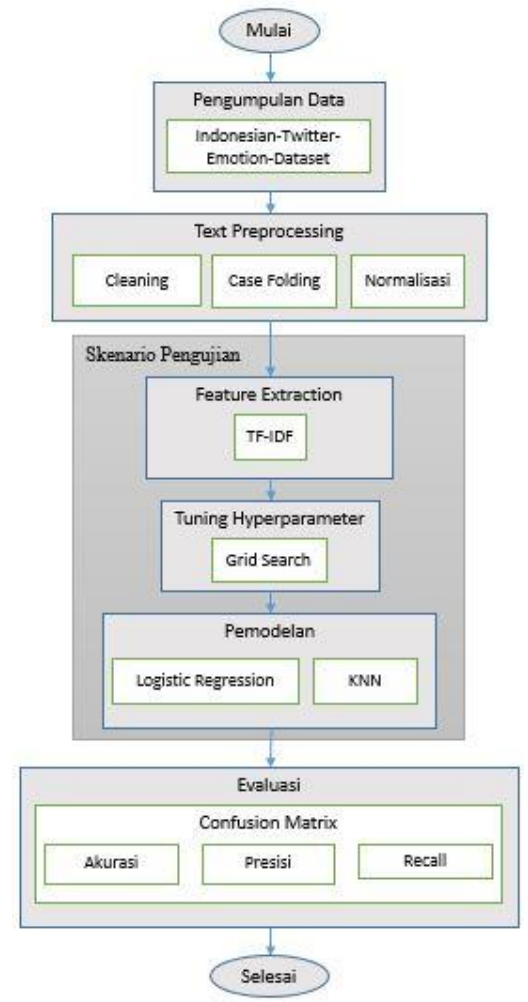

Gambar. 1 Metode penelitian

label, tweet

"anger", "Soal jln Jatibaru, polisi tdk bs GERTAK gubernur

Emangny polisi tdk ikut pmbhasan? Jgn berpolitik. Pengaturan wilayah, hak gubernur. Persoalan Tn Abang soal turun temurun.Pelik.Perlu kesabaran. [USERNAME] [USERNAME] [URL]""";"

"anger","Sesama cewe lho (kayaknya), harusnya bisa lebih rasain lah yang harus sibuk jaga diri, rasain sakitnya haid, dan paniknya pulang malem sendirian. Gimana orang asing? Wajarlah banyak korban yang takut curhat, bukan dibela malah dihujat." "";"

"happy", "Kepingin gudeg mbarek Bu hj. Amad Foto dari google, sengaja, biar teman-teman jg membayangkannya. Berbagi itu indah." " ;"

Gambar. 2 Indonesian Twitter emotion dataset

TABEL I

JUMLAH DATASET

\begin{tabular}{|l|l|}
\hline Label & $\begin{array}{l}\text { Indonesian-Twitter- } \\
\text { Emotion-Dataset }\end{array}$ \\
\hline Anger & 1102 \\
\hline Fear & 649 \\
\hline Sadness & 998 \\
\hline Love & 637 \\
\hline Happy & 1017 \\
\hline Total & 4403 \\
\hline
\end{tabular}

\section{B. Text Preprocessing}

Penelitian ini menggunakan tools Notebook Jupyter dengan menggunakan bahasa pemograman Python. Dataset yang digunakan adalah Indonesian-Twitter-EmotionDataset. Label adalah kelas emosi yang terdiri dari cinta, marah, sedih, senang, dan takut, sedangkan tweet merupakan kumpulan tweet dari pengguna Twitter berbahasa Indonesia. Data tersebut kemudian diinisialisasi 
ke dalam Notebook Jupyter untuk pra-pemrosesan teks. Hasil inisialisasi data dapat dilihat pada Gambar 2.

\begin{tabular}{lrr} 
& label & tweet \\
\hline 0 & anger & Soal jln Jatibaru,polisi tdk bs GERTAK gubernu... \\
1 & anger & Sesama cewe lho (kayaknya), harusnya bisa lebi... \\
2 & happy & Kepingin gudeg mbarek Bu hj. Amad Foto dari go... \\
3 & anger & Jin Jatibaru,bagian dari wilayah Tn Abang.Peng... \\
4 & happy & Sharing pengalaman aja, kemarin jam 18.00 bata...
\end{tabular}

Gambar. 2 Indonesian Twitter emotion dataset

Text Preprocessing adalah tahap dimana data mentah ditransformasikan menjadi data yang tersetrukur sehingga dapat dibaca oleh anotator atau orang yang mengklasifikasi data. Data mentah yang di dapat dari pengguna dapat berisi data noisy yang tidak diperlukan. Text Preprocessing membersihkan data dengan menghapus URL, nama pengguna, stopword (kata yang kurang penting) dan semua data yang tidak relevan yang tidak mengekspresikan emosi apa pun untuk meningkatkan efisensi [9].

Text Preprocessing pada penelitian ini menggunakan bahasa pemrograman Python yang memanfaatkan library seperti Natural Language Toolkit (NLTK), Sastrawi, Pandas, dan lainnya. Adapun tahapan-tahapan Text Preprocessing yang dilakukan sebagai berikut:

1) Cleaning: Pada penelitian ini Text Preprocessing dimulai dengan proses Cleaning. Cleaning merupakan proses membersihkan text dari tag html, link, script dan komponen lainnya yang tidak memiliki kaitan informasi pada kalimat. Pada penelitian ini proses Cleaning yang dilakukan adalah menghapus term yang telah dilakukan Text Preprocessing sebelumnya yaitu [USERNAME], [URL], [SENSITIVE-NO] dan hashtag. Contoh Cleaning dapat dilihat pada Gambar 3.

\begin{tabular}{|c|c|}
\hline Teks Input & Teks Output \\
\hline $\begin{array}{l}\text { Soal jln Jatibaru,polisi tdk bs } \\
\text { GERTAK gubernur .Emangny polisi } \\
\text { tdk ikut pmbhasan? Jgn berpolitik. } \\
\text { Pengaturan wilayah,hak gubernur. } \\
\text { Persoalan Tn Abang soal turun } \\
\text { temurun.Pelik.Perlu kesabaran. } \\
\text { [USERNAME] [USERNAME] [URL]";" }\end{array}$ & $\begin{array}{l}\text { Soal jln Jatibaru,polisi tdk bs } \\
\text { GERTAK gubernur .Emangny polisi } \\
\text { tdk ikut pmbhasan? Jgn berpolitik. } \\
\text { Pengaturan wilayah,hak gubernur. } \\
\text { Persoalan Tn Abang soal turun } \\
\text { temurun.Pelik.Perlu kesabaran. [] [] } \\
\text { []";" }\end{array}$ \\
\hline
\end{tabular}

Gambar. 3 Cleaning

2) Case Folding: Tujuan dari case folding pada penelitian ini yaitu mengubah semua huruf pada kalimat menjadi huruf kecil. Contoh case folding dapat dilihat pada Gambar 4.

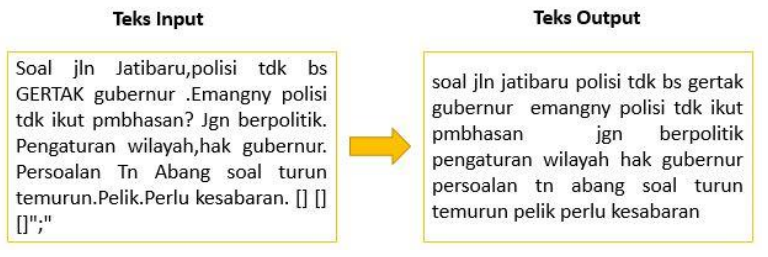

Gambar. 4 Case folding
3) Normalisasi: Tweet pada Twitter memiliki teks yang pendek dengan kata-kata tidak baku dan tata bahasa tidak terstruktur. Tujuan dari normalisasi adalah untuk mengubah kata yang tidak baku menjadi baku. Contoh Normalisasi dapat dilihat pada Gambar 5.

\begin{tabular}{|l|l|}
\hline \multicolumn{1}{|c|}{ Teks Input } & \multicolumn{1}{c|}{ Teks Output } \\
\hline $\begin{array}{l}\text { soal jln jatibaru polisi tdk bs gertak } \\
\text { gubernur emangny polisi tdk ikut } \\
\text { pmbhasan jgn berpolitik } \\
\text { pengaturan wilayah hak gubernur } \\
\text { persoalan tn abang soal turun } \\
\text { temurun pelik perlu kesabaran }\end{array}$ & $\begin{array}{l}\text { soal jalan jatibaru polisi tidak bisa } \\
\text { gertak gubernur emangnya polisi } \\
\text { tidak ikut pmbhasan jangan } \\
\text { berpolitik pengaturan wilayah hak } \\
\text { gubernur persoalan tanah abang } \\
\text { soal turun temurun pelik perlu } \\
\text { kesabaran }\end{array}$ \\
\hline
\end{tabular}

Gambar. 5 Normalisasi

\section{Feature extraction}

Feature extraction adalah proses memilih serangkaian fitur dari beberapa cara mengurangi dimensi ruang fitur [10]. Feature extraction dapat meningkatkan accuracy dan mempersingkat waktu pembelajaran. Seleksi dari bagian kalimat dapat mencerminkan informasi tentang kata-kata konten, dan perhitungan bobot disebut ekstraksi fitur teks. Feature extraction yang digunakan dalam penelitian ini yaitu pembobotan TF-IDF.

Pembobotan TF-IDF terdiri dari dua proses yaitu atau Term Frequency (TF) dan Inverse Document Frequency (IDF). Term Frequency (TF) merupakan banyaknya kemunculan sebuah term atau kata pada suatu kalimat. Semakin banyak term atau kata dalam suatu kalimat, maka semakin besar nilai bobotnya [11]. Sedangkan Inverse Document Frequency (IDF) Menurut Riyanto merupakan banyaknya kemunculan term dalam kumpulan kalimat [12] Berbeda dengan TF, pada IDF jika semakin banyak kemunculan term atau kata pada seluruh kalimat pada dataset, maka semakin kecil nilainya. jika semakin sedikit kemunculan term atau kata pada seluruh dokumen, maka semakin besar nilainya.

Pada penelitian ini untuk memulai proses TF-IDF hal pertama yang harus dilakukan yaitu membuat CountVectorizer untuk menghitung jumlah kata (Term Frequency) yang telah tersimpan pada variabel count_vect untuk diterapkan dengan menggunakan fit_transform pada variabel X_count (lihat Gambar 6). Kemudian untuk menghitung nilai IDF yaitu dengan memanggil TfidfTransformer yang telah tersimpan pada variabel tfidf_transformer untuk diterapkan dengan menggunakan fit_transform pada variabel X_tfidf.

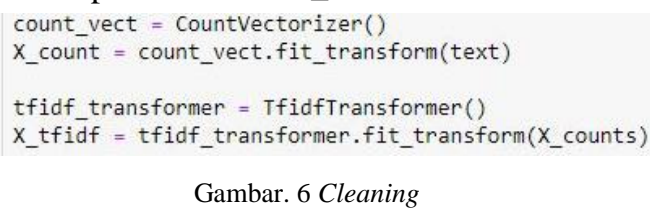

Gambar. 6 Cleaning

\section{Tuning Hyperparameter}

Tuning Hyperparameter Tuning merupakan pemilihan hyperparameter yang optimal pada algoritma pembelajaran. Salah satu cara untuk memilih kombinasi hyperparameter yaitu dengan Grid Search. Grid Search akan mengkombinasikan hyperparamater-hyperparameter yang 
dimasukkan dan mencari kombinasi hyperparameter dengan nilai akurasi yang paling tinggi.

Tuning Hyperparameter pada penelitian ini dilakukan dengan menggunakan Grid Search. Grid Search pada python dilakukan dengan cara mengimport class GridSearchCV pada library sklearn. Pada penelitian ini hyperparameter yang diuji yaitu nilai $\mathrm{C}$ pada Logistic Regression dan nilai K pada K-Nearest Neighbor.

\section{E. Pemodelan}

Terdapat dua Pendekatan yang dipilih untuk melakukan klasifikasi pada penelitian ini, yaitu Logistic Regression dan K-Nearest Neighbor.

1) Logistic Regression: Logistic Regression merupakan model regresi untuk menganalisis hubungan antara suatu variabel dependent dan satu atau lebih variabel independent. Variabel dependent terdiri dari dua kategori yaitu "ya (sukses)" dan "tidak (gagal)" dan dinotasikan 1="sukses" dan 0="gagal" [13],[14],[15]. Pemodelan Logistic Regression pada penelitian ini memanfaatkan fungsi LogisticRegression dari library Sklearn. Berikut Bentuk model Logistic Regression:

$$
\log \left(\frac{P}{1-P}\right)=\beta 0+\beta 1 X 1+\beta 2 X 2+\ldots+\beta K X K(1)
$$

Sebelumnya hyperparameter yang sesuai pada Logistic Regression telah dicari menggunakan Grid Search. Hyperparamaters yang diuji yaitu nilai C.

2) K-Nearest Neighbor: K-Nearest Neighbor adalah metode klasifikasi objek terhadap data pelatihan dengan pemilihan kelas objek berdasarkan jarak terdekat dari data pelatihannya. Berdasarkan atribut dan sample dari data training algoritma ini dapat mengklasifikasikan objek baru. KNN adalah metode klasifikasi dengan cara menghitung nilai K (Neighbor). K merupakan titik neighbor objek, nilai $\mathrm{K}$ akan dibandingkan untuk menentukan klasifikasi objek tersebut [16],[17]. Pemodelan K-Nearest Neighbors pada penelitian ini dilakukan dengan menggunakan bahasa pemrograman Python yang memanfaatkan fungsi KNeighborsClassifier dari library Sklearn. Tahapan untuk menjalani proses KNN sebagai berikut (Alm, Roth, and Sproat 2005):

- Menentukan jumlah pada tetangga $\mathrm{k}$.

- Menghitung jarak objek dengan masing-masing data kelompok. Perhitungan jarak menggunakan rumus euclidian distance [18] yang ditunjukan pada persamaan 4. Dimana D adalah jarak, $x$ dan y adalah data latih dan data uji.

$$
D(x, y)=\sqrt{\sum_{k=1}^{n}(x i-y i)^{2}}
$$

- Lalu didapatkan hasil pengklasifikasian.

Sebelumnya hyperparameter yang sesuai K-Nearest Neighbor telah dicari menggunakan Grid Search. Hyperparamaters yang diuji yaitu nilai $\mathrm{K}$.

3) Skenario Pengujian: Terdapat empat skenario pengujian pada masing-masing algoritma Logistic Regression dan K-Nearest Neighbor (lihat Tabel 2). Skenario pengujian pertama dilakukan menggunakan feature extraction TF dan algoritma klasifikasi dengan default hyperparameter. Skenario pengujian kedua dilakukan menggunakan feature extraction TF-IDF dan algoritma klasifikasi dengan default hyperparameter. Skenario pengujian ketiga dilakukan menggunakan feature extraction TF dan algoritma klasifikasi dengan Tuning Hyperparameter. Skenario pengujian keempat dilakukan menggunakan feature extraction TF-IDF dan algoritma klasifikasi dengan tuning hyperparameter.

TABEL II

JUMLAH DATASET

\begin{tabular}{|l|c|c|}
\hline Skenario Pengujian & $\begin{array}{c}\text { Tuning } \\
\text { Hyperparameter }\end{array}$ & $\begin{array}{c}\text { Feature } \\
\text { extraction IDF }\end{array}$ \\
\hline $\begin{array}{l}\text { Skenario pengujian } \\
\text { pertama }\end{array}$ & $\mathbf{x}$ & $\mathbf{x}$ \\
\hline $\begin{array}{l}\text { Skenario pengujian } \\
\text { kedua }\end{array}$ & $\mathbf{x}$ & $\checkmark$ \\
\hline $\begin{array}{l}\text { Skenario pengujian } \\
\text { ketiga }\end{array}$ & $\checkmark$ & $\mathbf{x}$ \\
\hline $\begin{array}{l}\text { Skenario pengujian } \\
\text { kedua }\end{array}$ & $\checkmark$ & $\checkmark$ \\
\hline
\end{tabular}

\section{F. Evaluasi}

Pada penelitian ini 10-Fold Cross validation digunakan dalam membagi data set secara bergantian menjadi data test dan data training untuk mendapatkan nilai prediksi data test. Kemudian hasil prediksi dari mesin dibandingkan dengan data label untuk di evaluasi menggunakan Confusion Matrix. Untuk menjelaskan keterhubungan antar bagian dalam model klasifikasi maka dapat dilihat dari arsitektur sistem yang dibangun. Arsitektur sistem digunakan untuk menjelaskan rencana atau pemetaan dari proses-proses yang akan dilakukan dalam membangun emotion mining machine.

Gambar 7 merupakan arsitektur sistem pada penelitian ini. Langkah pertama, Data yang telah dikumpulkan dari penelitian yang telah dipublikasikan oleh putri dkk [5] dilakukan Text Mining untuk membersihkan dan mengekstrak kalimat-kalimat yang ada pada dataset. Kemudian dari data tersebut dijadikan bahan pembelajaran untuk membuat model Machine Learning. Hasil pemodelan kemudian dilakukan pengujian dengan Confusion Matrix untuk mendapatkan nilai Accuracy, Precision, Recall, dan F1-score model machine learning. Selain itu user dapat melakukan percobaan dengan memasukkan sebuah teks/kalimat dan model akan melakukan prediksi emosi terhadap teks/kalimat masukkan. 


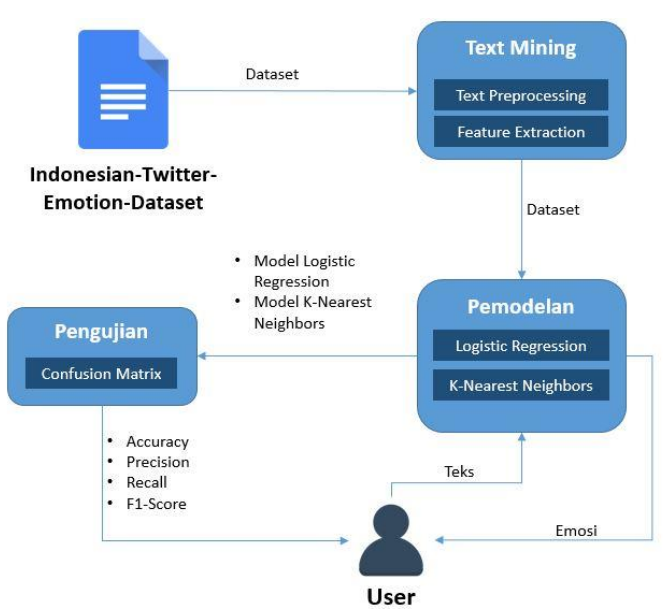

Gambar. 7 Arsitektur sistem

\section{HASIL DAN PEMBAHASAN}

Tahap-tahap yang dilakukan untuk membuat model machine learning mulai dari pengumpulan data, preprocessing, feature extraction, hingga pemodelan telah dilakukan. Terdapat delapan model dibuat pada penelitian ini. Data uji pada setiap model dibagi menggunakan 10 Fold Cross Validation. Hasil Prediksi data uji dibandingkan dengan label untuk dievaluasi menggunakan Confusion Matrix.

\section{A. Hasil Implementasi Text Preprocessing}

Hasil sample dataset dari keseluruhan Text Preprocessing ditampilkan dalam bentuk tabel yang dapat dilihat pada Tabel 3 .

TABEL III

HASIL TEXT PREPROCESSING

\begin{tabular}{|l|l|}
\hline \multicolumn{1}{|c|}{ Text } & $\begin{array}{c}\text { Text } \\
\text { Preprocessing }\end{array}$ \\
\hline $\begin{array}{l}\text { Soal jln Jatibaru,polisi tdk bs GERTAK } \\
\text { gubernur.Emangny polisi tdk ikut pmbhasan? }\end{array}$ & $\begin{array}{l}\text { Tanpa } \\
\text { Preprocessing }\end{array}$ \\
Jgn berpolitik. Pengaturan wilayah,hak \\
gubernur. Persoalan Tn Abang soal turun \\
temurun.Pelik.Perlu kesabaran. \\
[USERNAME] [USERNAME] [URL]";"
\end{tabular}

\section{B. Hasil Implementasi Text Preprocessing}

Berikut adalah Gambar 8 yang menampilkan hasil dari Feature extraction.

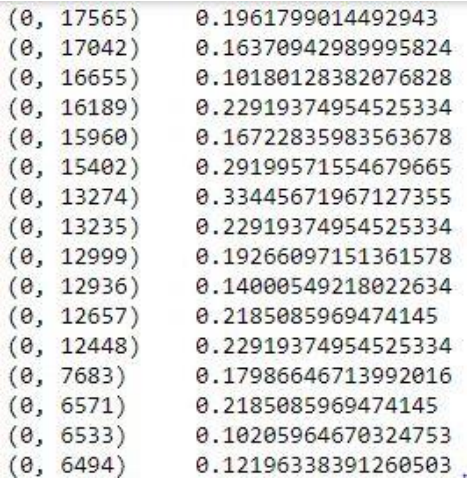

Gambar. 8 Hasil TF-IDF

Keterangan:

$$
\begin{array}{ll}
\text { 1. } & \text { Document Index } \\
\text { 2. } & \text { Word Index } \\
\text { 3. } & \text { TF-IDF Score }
\end{array}
$$

\section{Hasil Implementasi Hyperparameter Tuning}

Model yang tidak dan menggunakan TF-IDF menghasilkan nilai dari Tuning Hyperparameter yang berbeda. Hasil Tuning Hyperparameter dapat dilihat Pada Tabel 4.

TABEL IV

HASIL HYPERPARAMETER TUNING

\begin{tabular}{|l|l|l|}
\hline $\begin{array}{l}\text { Algoritma } \\
\text { Klasifikasi }\end{array}$ & Tanpa TF-IDF & $\begin{array}{l}\text { Menggunakan } \\
\text { TF-IDF }\end{array}$ \\
\hline $\begin{array}{l}\text { Logistic } \\
\text { Regression }\end{array}$ & $\begin{array}{l}\mathrm{C}= \\
0.08858667904100823\end{array}$ & $\begin{array}{l}\mathrm{C}= \\
1.623776739188721\end{array}$ \\
\hline $\begin{array}{l}\text { K-Nearest } \\
\text { Neighbor }\end{array}$ & $\mathrm{K}=44$ & $\mathrm{~K}=43$ \\
& & \\
\hline
\end{tabular}

\section{Hasil Evaluasi Logistic Regression}

Berikut adalah Tabel 5 yang menampilkan hasil evaluasi dari keempat model Logistic Regression. Confusion Matrix model pertama hingga keempat dapat dilihat pada Gambar 9-12.

TABELV

HASIL EVALUASI MODEL LOGISTIC REGRESSION

\begin{tabular}{|l|l|l|l|l|}
\hline $\begin{array}{c}\text { Performa } \\
\text { Model }\end{array}$ & $\begin{array}{c}\text { Model } \\
\text { Pertama }\end{array}$ & $\begin{array}{c}\text { Model } \\
\text { Kedua }\end{array}$ & $\begin{array}{c}\text { Model } \\
\text { Ketiga }\end{array}$ & $\begin{array}{c}\text { Model } \\
\text { Keempat }\end{array}$ \\
\hline Accuracy & $64 \%$ & $64 \%$ & $64 \%$ & $65 \%$ \\
\hline Precison & $67 \%$ & $69 \%$ & $67 \%$ & $69 \%$ \\
\hline Recall & $65 \%$ & $63 \%$ & $64 \%$ & $64 \%$ \\
\hline F1-score & $65 \%$ & $65 \%$ & $65 \%$ & $66 \%$ \\
\hline
\end{tabular}




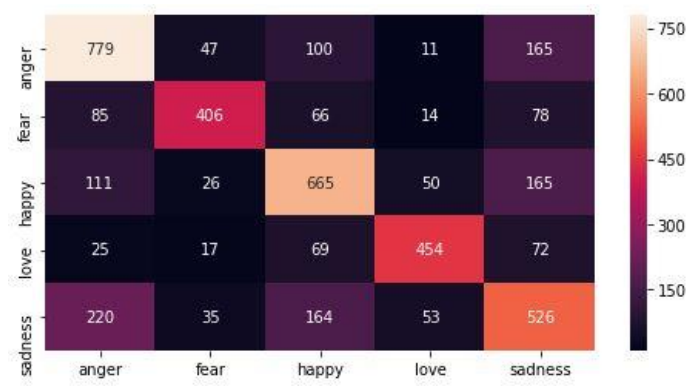

Gambar. 9 Confusion matrix model pertama logistic regression

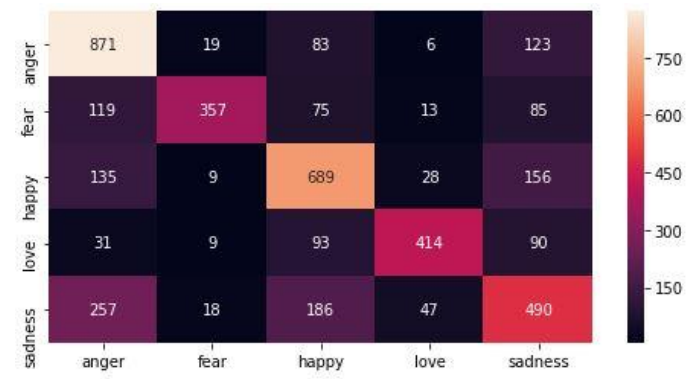

Gambar. 10 Confusion matrix model kedua logistic regression

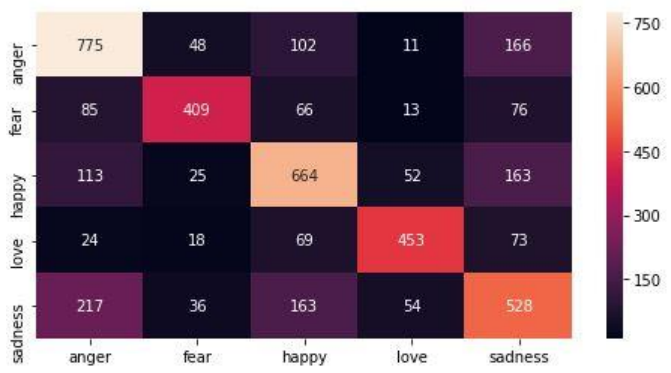

Gambar. 11 Confusion matrix model ketiga logistic regression

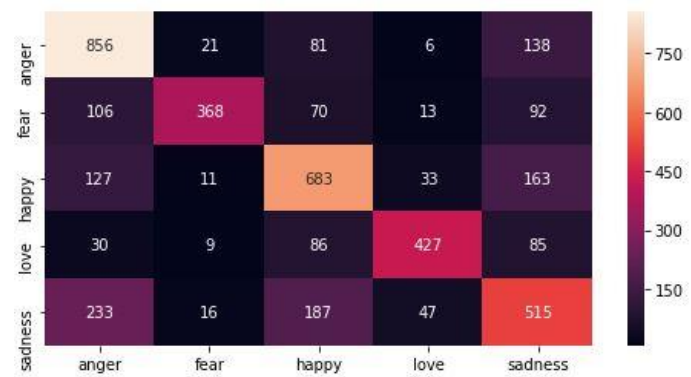

Gambar. 12 Confusion matrix model keempat logistic regression

\section{E. Hasil Evaluasi Model K-Nearest Neighbors}

Berikut adalah Tabel 6 yang menampilkan hasil evaluasi Logistic Regression. Confusion Matrix model pertama hingga keempat dapat dilihat pada Gambar 13, 14, 15, 16.
TABEL VI

HASIL EVALUASI MODEL $K$-NEAREST NEIGHBORS

\begin{tabular}{|c|c|c|c|c|}
\hline $\begin{array}{c}\text { Performa } \\
\text { Model }\end{array}$ & $\begin{array}{c}\text { Model } \\
\text { Pertama }\end{array}$ & $\begin{array}{c}\text { Model } \\
\text { Kedua }\end{array}$ & $\begin{array}{c}\text { Model } \\
\text { Ketiga }\end{array}$ & $\begin{array}{c}\text { Model } \\
\text { Keempat }\end{array}$ \\
\hline Accuracy & $33 \%$ & $49 \%$ & $34 \%$ & $55 \%$ \\
\hline $\begin{array}{c}\text { Performa } \\
\text { Model }\end{array}$ & $\begin{array}{c}\text { Model } \\
\text { Pertama }\end{array}$ & $\begin{array}{c}\text { Model } \\
\text { Kedua }\end{array}$ & $\begin{array}{c}\text { Model } \\
\text { Ketiga }\end{array}$ & $\begin{array}{c}\text { Model } \\
\text { Keempat }\end{array}$ \\
\hline Precison & $39 \%$ & $48 \%$ & $42 \%$ & $56 \%$ \\
\hline Recall & $32 \%$ & $50 \%$ & $30 \%$ & $57 \%$ \\
\hline F1-score & $31 \%$ & $48 \%$ & $29 \%$ & $55 \%$ \\
\hline
\end{tabular}

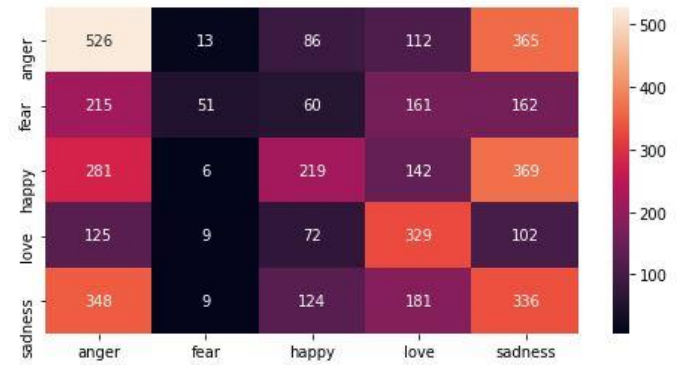

Gambar. 13 Confusion matrix model pertama K-Nearest Neighbor

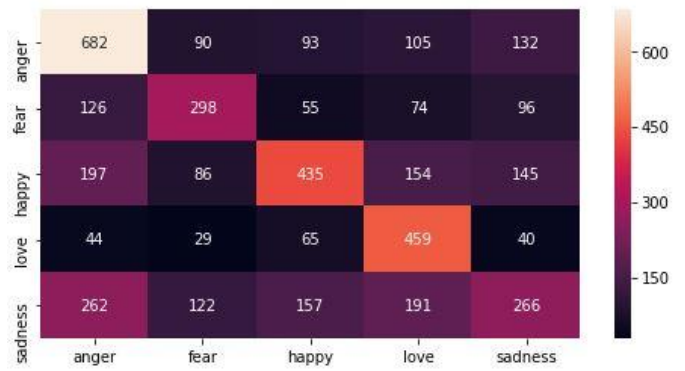

Gambar. 14 Confusion matrix model kedua K-Nearest Neighbor

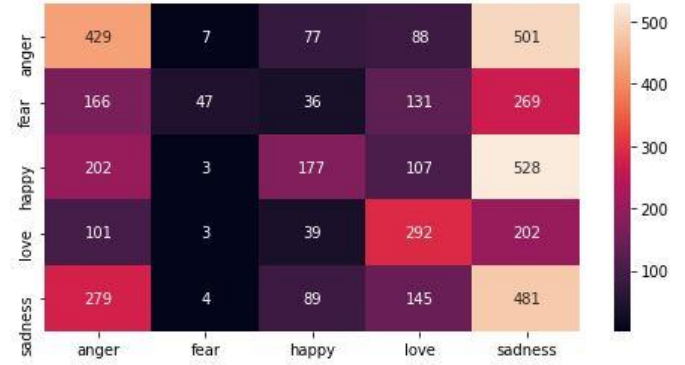

Gambar. 15 Confusion matrix model ketiga K-Nearest Neighbor

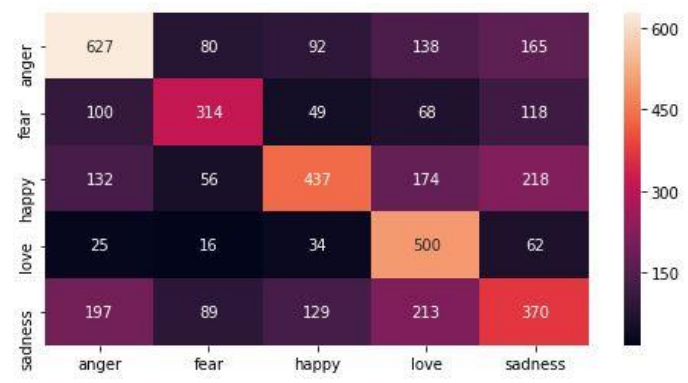

Gambar. 16 Confusion matrix model keempat K-Nearest Neighbor 


\section{F. Analisis Logistic Regression}

Hasil evaluasi pada Logistic Regression (lihat Tabel 5) menunjukkan bahwa model keempat memperoleh hasil performa yang paling baik dengan nilai accuracy dan $f 1$ score $65 \%$ dan $66 \%$. Model keempat yaitu model yang menggunakan TF-IDF dan Hyperparameter $\mathrm{C}=1.623776739188721$. Confusion Matrix model keempat pada Logistic Regression dapat dilihat pada Gambar 12.

Selain itu, Hasil evaluasi Logistic Regression pada model kedua menunjukkan pengaruh TF-IDF. Hasil dari model kedua menunjukkan bahwa dengan TF-IDF nilai precision mengalami kenaikan sebesar 2,985\% namun pada nilai recall mengalami penurunan sebesar 3,077\%.

Hasil evaluasi Logistic Regression pada model ketiga menunjukkan pengaruh Tuning Hyperparameter. Hasil dari model ketiga menunjukkan bahwa dengan Tuning Hyperparameter nilai precision mengalami penurunan 1,538\%. Dan hasil dari model keempat menunjukkan bahwa dengan TF-IDF dan Tuning Hyperparameter nilai accuracy, precision, dan F1-score masing-masing mengalami kenaikan sebesar 1,5625\%; 2,985\% dan 1,538\% namun nilai recall mengalami penurunan sebesar $1,538 \%$.

Di sisi lain, Confusion Matrix Logistic Regression pada keempat model menunjukkan kesalahan prediksi yang paling banyak terjadi yaitu kalimat pada kelas Sadness yang terprediksi sebagai kelas Anger dan Happy, akibatnya nilai recall menjadi rendah. Kemudian kesalahan yang paling banyak terjadi juga kalimat pada kelas Anger dan Happy yang terprediksi kelas Sadness, akibatnya nilai precision menjadi rendah.

\section{G. Analisis K-Nearest Neighbors}

Hasil evaluasi pada K-Nearest Neighbors (lihat Tabel 4.4) menunjukkan bahwa model keempat memperoleh hasil performa yang paling baik dengan nilai accuracy dan fl-score 55\% dan 55\%. Model keempat yaitu model yang menggunakan TF-IDF dan Hyperparameter $\mathrm{K}=43$. Confusion Matrix Skenario keempat pada K-Nearest Neighbors dapat dilihat pada Gambar 4.9.

Confusion Matrix pada model keempat menunjukkan bahwa rendahnya nilai akurasi disebabkan oleh banyaknya kalimat yang tidak terprediksi tidak tepat sesuai dengan kelasnya. Kesalahan prediksi yang paling banyak terjadi yaitu pada kelas sadness yang terprediksi sebagai kelas anger dan happy, akibatnya nilai recall menjadi rendah. Kemudian kesalahan prediksi yang paling banyak terjadi juga pada kelas happy dan anger yang terprediksi sebagai kelas anger, akibatnya nilai precision menjadi rendah.

Selain itu, hasil dari model kedua menunjukkan bahwa dengan TF-IDF nilai accuracy, precision, recall, dan f1score masing-masing mengalami kenaikan sebesar 48,5\%; 23,08\%; 56,25\%; dan 54,84\%. Dan hasil dari model ketiga menunjukkan bahwa dengan Tuning Hyperparameter nilai accuracy dan precision masing-masing mengalami kenaikan sebesar 3,03\% dan 7,69\% namun nilai recall dan fl-score masing-masing mengalami penurunan sebesar 6,25\% dan 6,45\%. Dan Hasil dari Skenario 4 menunjukkan bahwa dengan TFIDF dan Tuning Hyperparameter nilai accuracy, precision, recall, dan f1-score masing-masing mengalami kenaikan sebesar 66,7\%; 43,6\%; 78,125; dan $77,42 \%$

\section{H. Perbandingan Hasil Evaluasi Logistic Regression dan K-Nearest Neighbors}

Hasil evaluasi Logistic Regression (lihat Tabel 5) dan $K$ Nearest Neighbors (lihat Tabel 6) menunjukkan bahwa Logistic Regression pada model keempat menghasilkan performa terbaik dengan nilai accuracy dan fl-score masin-masing sebesar $65 \%$ dan $66 \%$. Sedangkan algoritma K-Nearest Neighbors memiliki nilai Accuracy dan fl-score masing-masing sebesar $55 \%$ dan $55 \%$.

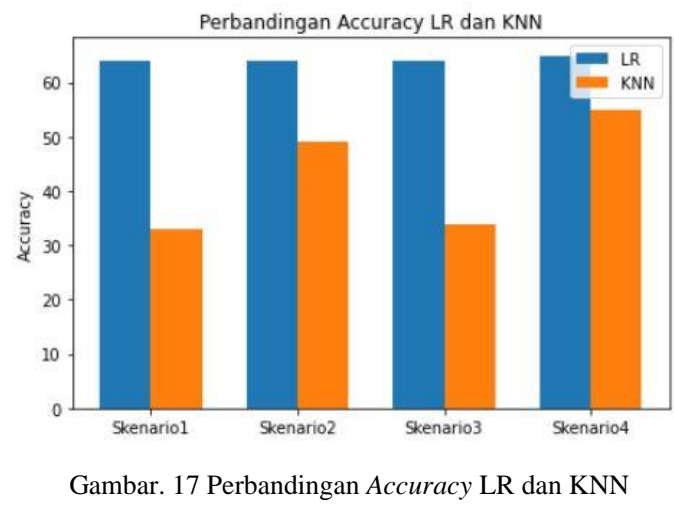

Hasil evaluasi Logistic Regression pada keempat model memiliki hasil performa yang lebih baik dibandingkan menggunakan algoritma K-Nearest Neighbors (lihat Gambar 17). Namun penggunaan TF-IDF atau Tuning Hyperparameters tidak memiliki pengaruh terhadap nilai accuracy Logistic Regression. Dan pada skenario 4 hanya meningkatkan accuracy sebesar 1,5625\%. Disisi lain penggunaan TF-IDF dan Tuning Hyperparameters pada $K$ Nearest Neighbors dapat meningkatkan nilai accuracy dan fl-score masing-masing hingga $66,7 \%$ dan $77,42 \%$.

\section{Prediksi Emosi}

Judul Penelitian: Perbandingan Algoritma Klasifikasi terhadap Emosi Tweet Berbahasa Indonesia Dataset: Indonesian-Twitter-Emotion-Dataset

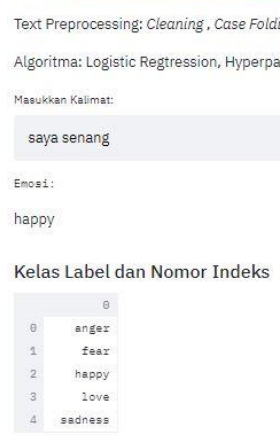

Probabilitas Prediks

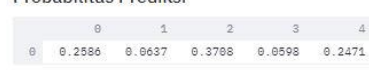

Gambar. 18 Tampilan aplikasi 


\section{Implementasi aplikasi generik}

Aplikasi generik yang dibangun berdasarkan model dengan hasil evaluasi paling baik yaitu Logistic Regression dengan Hyperparameter $\mathrm{C}=1.623776739188721$ dan feature extraction TF-IDF. Aplikasi generik yang dibangun berbasis web dengan fitur prediksi dengan mengisi teks kedalam kolom input. Kemudian setelah diinput teks hasil output aplikasi yaitu prediksi emosi dari teks yang diinputkan dan probabilitas prediksi tersebut. Tampilan dari Aplikasi generik dapat dilihat pada Gambar 18. Aplikasi generik dapat di akses pada link https://predictemotion.herokuapp.com/.

\section{KESIMPULAN}

Berdasarkan hasil penelitian yang telah dilakukan maka dapat disimpulkan sebagai berikut.

1. Performa model logistic regression jika menggunakan TF-IDF dan Tuning Hyperparameter memberikan perfoma pengujian paling baik dengan nilai accuracy dan $f 1$-score masing-masing sebesar $65 \%$ dan $66 \%$. Sedangkan hasil pengujian pada algoritma K-Nearest Neighbor memberikan performa accuracy dan fl-score sebesar 55\%.

2. Penggunaan feature extraction Tf-Idf lebih berpengaruh terhadap algoritma $K$-Nearest Neighbors yang dapat meningkatkan nilai accuracy dan $f 1$-score masing-masing sebesar $48,4 \%$ dan $54,84 \%$ dibandingkan dengan Logistic regression yang hanya dapat meningkatkan nilai precision sebesar 2,985\%.

3. Penggunaan Tuning Hyperparameter lebih berpengaruh terhadap kedua algoritma apabila menggunakan feature extraction TF-IDF. Penggunaan TF-IDF dan Tuning Hyperparameter dapat meningkatkan nilai accuracy dan f1-score pada Logistic Regression masing-masing sebesar $1,5625 \%$ dan $1,538 \%$ dan pada $K$-Nearest Neighbor masing-masing sebesar $66,7 \%$ dan $77,42 \%$.

\section{REFERENSI}

[1] Phuvipadawat, S. and Murata, T. Breaking news detection and tracking in Twitter. Proceedings - 2010 IEEE/WIC/ACM International Conference on Web Intelligence and Intelligent Agent Technology - Workshops, WI-IAT:120-123.

[2] Hirat, R. 2015. A Survey On Emotion Detection Techniques using Text in Blogposts. International Bulletin of Mathematical Research. 2(1): $180-187$

[3] P. R. Shaver, U. Murdaya, and R. C. Fraley, "Structure of the Indonesian Emotion Lexicon," Asian Journal of Social Psychology, vol. 4, no. 3, pp. 201-224, 2001.

[4] The. J. E., A. F. Wicaksono, and M. Adriani. 2015. A two-stage emotion detection on indonesian tweets. In Advanced Computer Science and Information Systems (ICACSIS). Pages 143-146.
[5] Saputri, Mei Silviana, Rahmad Mahendra, and Mirna Adriani. 2019 "Emotion Classification on Indonesian Twitter Dataset." Proceedings of the 2018 International Conference on Asian Language Processing, IALP 2018 (January 2019):90-95.

[6] Alm, Cecilia Ovesdotter, Dan Roth, and Richard Sproat. 2005 "Emotions from Text: Machine Learning for Text-Based Emotion Prediction." HLT/EMNLP 2005 - Human Language Technology Conference and Conference on Empirical Methods in Natural Language Processing, Proceedings of the Conference (October):579-86.

[7] Pranckevičius, Tomas, and Virginijus Marcinkevičius. 2017. "Comparison of Naive Bayes, Random Forest, Decision Tree, Support Vector Machines, and Logistic Regression Classifiers for Text Reviews Classification.” Baltic Journal of Modern Computing 5(2):221-32.

[8] Azam, Muhammad, Tanvir Ahmed, Fahad Sabah, and Muhammad Iftikhar Hussain. 2018. "Feature extraction Based Text Classification Using K-Nearest Neighbor Algorithm." IJCSNS International Journal of Computer Science and Network Security 18(12):95-101.

[9] Pinto, Joylin Priya, and Vijaya Murari. 2008. "Real Time Sentiment Analysis of Political Twitter Data Using Machine Learning Approach." International Research Journal of Engineering and Technology 4124.

[10] D Trier, AK Jain, dan T Taxt. 1996. Feature extraction methods for character recognition - a survey. Pattern Recogn. 29(4), 641662.

[11] Muslim, AA. 2016. Rancang Bangun Aplikasi Berbasis Web untuk Analisis Sentimen pada Mikroblog Twitter dengan Metode Naive Bayes. Electronic Theses Universitas Islam Negeri Maulana Malik Ibrahim.

[12] Riyanto, A. 2016. Text Summarization dengan Metode K-Means Pada Artikel Berita Berbahasa Indonesia. Digital Library UNIKOM.

[13] Rachimawan, Achmad Fachrudin. 2016. "ADS Filtering Menggunakan Jaringansyaraf Tiruan Perceptron, Naïve Bayes Classifier Dan Regresi Logistik." 5(1):98.

[14] Saputra, Rizal Amegia. 2014. "Komparasi Algoritma Klasifikas Data Mining Untuk Memprediksi Penyakit Tuberculosis ( Tb ): Studi Kasus Puskesmas Karawang." Seminar Nasional Inovasi Dan Tren (SNIT) (April):1-8.

[15] Intansari, Ida Ayu Sevita, Santi Wulan Purnami, and Sri Pingit Wulandari. 2012. "Klasifikasi Pasien Hasil Pap Smear Test Sebagai Pendeteksi Awal Upaya Penanganan Dini Pada Penyakit Kanker Serviks Di RS. ' $X$ ' Surabaya Dengan Metode Bagging Logistic Regression.” Jurnal Sains Dan Seni ITS 1(1):D277-82.

[16] Rahmadianto, Rizky, Edy Mulyanto, and T. Sutojo. 2019. "Implementasi Pengolahan Citra Dan Klasifikasi K-Nearest Neighbor Untuk Mendeteksi Kualitas Telur Ayam.” Jurnal VOI (Voice Of Informatics) 8(1):45-54.

[17] Abdurrahman, Muhammad Hanif, Efri Suhartono, and Eka Wulandari. 2019. "Deteksi Kualitas Kemurnian Susu Sapi Melalui Pengolahan Citra Digital Menggunakan Metode Scale Invariant Feature Transform ( Sift ) Dan Klasifikasi K-Nearest Neighbor ( Knn ) Quality Detection of Cow' S Milk Purity Using Digital Image Processing Method O.” 6(2):3845-52.

[18] Sreemathy. J., dan Balamurungan. P. S., 2012. An efficient text classification using KNN and naïve bayesian. International Journal on Computer Science and Engineering (IJCSE), vol. 4, no. 3, pp. 392-396. 